\title{
Online learning platform during Covid-19 pandemic: An exploratory factor analysis on students' attitude and perceived usefulness in media and communication education
}

\author{
Hasmah Zanuddin*, Nursyamira Shaid, Zulfadhli Halim \\ Department of Media and Communication Studies, Faculty of Arts and Social Sciences, University of Malaya, Kuala Lumpur, 50603, Malaysia
}

Article history:

Received: 19 March 2021 / Received in revised form: 15 June 2021 / Accepted: 21 June 2021

\begin{abstract}
Due to Covid-19 and Movement Control Order (MCO) policy, Malaysian Higher Learning institution has decided to shift the learning into online learning mode. In this research, we examined the readiness and attitude of the Media and Communication undergraduate students for online learning platform during pandemic. A total of 144 students' responses and Technology Acceptance Model (TAM) were used as theoretical framework. Research data were analyzed using SPSS and exploratory factor analysis (EFA) was utilised to extract the prominent factors. Component based examined using eigenvalue, scree plot and rotation was done by varimax method. The items with 0.5 loading or greater were considered significant. The findings showed that Perceived Usefulness was determined by two significant indicators, i.e. enhancing effectiveness in learning and improving learning performance with factor loadings; .869 and .849 consecutively. Attitude factor loading, meanwhile, showed that two indicators played a dominant role; using online learning is a bad idea throughout the coursework and positive attitude towards online learning and usefulness towards study; .762 and .816. The attitude of the students displayed unhappiness using the online learning platform for the entire semester due to the limitation of face-to-face (F2F) lab classes such as studio-based learning. However, the students had no problem in understanding the online platform utilized.
\end{abstract}

Keywords: Online learning; exploratory factor analysis; perceived usefulness; attitudes; technology acceptance model; covid-19

\section{Introduction}

The sudden pandemic attack worldwide has made halted and affected many things including education. Online learning or virtual learning and teaching is then designed to replace physical classroom. The sudden shift is deemed necessary in which the decision makers prioritise online teaching and establishes it as the new normal. Both students and academic have lost the holistic educational experience; eye contact, dynamics of body language, intrinsic human behavioural skills and socialisation that prepare the students to enter the work world. As early as first Movement Control Order (MCO) in February 2020, Malaysian higher learning institution decided for online learning approach. However, managing online classes can be tricky at times especially when internet data is the prominent agent to connect lecturers and students face to face in a way far better in direct learning contact with students. Online learning has become the new normal for all students at every level during the Covid-19 pandemic outbreak. University of Malaya (UM) has assisted students and lecturers for online classes by providing the online classroom environment and platform by subscribing the license of Microsoft Team. Fortunately, UM has designed Spectrum, a multi-platform portal way ahead from Covid19 and this portal offers various

* Corresponding author.

Email: hasmahz@um.edu.my

https://doi.org/10.21924/chss.1.1.2021.7 components of online services to lecturers and students. One of the components is Spectrum designed and made available to lecturers to share weekly lectures and class activities. Students can easily access Spectrum using their official email either for class attendance, downloading the class lectures, tutorial or for submitting the assignments. However, Spectrum has no capacity for online live classes compared to Microsoft Team. As an option, Google Meet can also be utilised by lecturers and students as UM is already on Google platform for email (UM Mail). Some may use Zoom Meeting platform but is it not advisable for online classroom as it limits only to 300 participants per meeting.

The readiness of both students and educators is questionable on the sudden pandemic outbreak as announced by the Higher Education Minister on March $15^{\text {th }} 2020$ that all learning processes must be conducted online and all higher education institutions are forced to close temporarily. This has forced the institution unwillingly to prepare themselves to switch and accept modern technology adaptation in teaching. This crisis also has revealed arguments on the benefits, downpours, challenges and effectiveness of online learning in higher education.

For many reasons, online learning has become a personal problem for certain people. Individually, each of the users (students and lecturers) finds every hardship facing personal online learning. For digital natives (the students) they may find it rather convenient to enter class online. While the professors 
who mainly are digital immigrants are struggling to learn and adapt the advanced technologies of online learning. In higher education, as an institution, every faculty has its own struggles in adapting physical lectures into online platform. The Science Faculty, for instance, has laboratory session in almost every course, and it is important for them to experience and has a hands-on practice on the experiments as a part of their learning process. On the other hand, the Media \& Communication studies also requires students to have a technical aspect of learning process such as graphic designing, video editing and filming, and studio recording. Media and Communications curriculum offers some technical aspects such graphic design, video editing, physical film/drama shooting, or broadcast studio management. It is very important to evaluate the effectiveness of online learning platform during Covid-19 pandemic. Survey was done online using Google Form on week 9, semester 1, session 2020/2021 (14-18 December, 2020). The curriculum was designed specifically to require physical and technical guidance. The faculty member, however, is not prepared for online designated curriculum for such subjects and courses. Thus, this research was aimed to examine the readiness and attitude of Media \& Communication Studies students of University of Malaya toward online learning during Covid-19 pandemic in Malaysia.

\section{Literature review}

The effectiveness and the acceptance of online learning have been explored since the introduction of the usage of online platform in Teaching and Learning. The usage of online medium as the side platform of teaching and learning has been seen an additional and supportive platform in teaching and learning of the physical classes. Micro-credential has become the development of online learning where teaching and learning is in the full mode virtual form. However, it is found that the institution and individuals involved are well-prepared mentally and physically in facing the online ambience and make it more enjoyable. During the outbreak of the Coronavirus pandemic, virtual teaching and learning from home is rather odd.

\subsection{The challenges of virtual teaching and learning from home}

With the existence and spike number of Covid-19 cases all over the world, including Malaysia, higher education has structured online learning for students. Thus, for the early part of MCO, unpreparedness institution across globe at every level utilize the available technical resources to create online learning materials for students (Kaur, 2020). The tensions and disruptions have resulted in the trauma of the pandemic in fact in the US (Schwartzman, R., 2020). However, online learning can be effective in the digitally advanced countries (Basilaia \& Kvavadze, 2020) but Malaysia is not far behind. Across nation, internet connection can be reached except in the rural area. However, in some countries all the academic management done manually find it difficult to manually adapt (Salam et al., 2017; Adnan \& Anwar, 2020). In the developing countries, students are reluctant on using online learning for having insufficient skills of practicing online learning, and insufficient support from the instructors (Farahat, 2012). The skills of utilizing these tools as alternative for face-to face class is needed
(Basilaila et al., 2020); however, the digital immigrant instructors have found it hard to adapt. Compared to the developed countries, they also find it difficult to curb with online learning especially when they have to leave their universities dormitory and have to bear with internet costing to get into online classes (Demuyakor, 2020).

Instructors are mainly digital immigrants that are not grown in the digital and technology era. Thus, the superior of digital literacy is one of the challenges in online learning. Although online learning has been practiced for sometimes, instructors does not adopt such learning form (Vendenhouten et al., 2014). The shift of physical class to online learning has become an issue for them even though University of Malaya has introduced a week of online learning implemented since 2017. Digital teaching and learning have allowed them to be the "facilitators, guides, collaborators and learners" which are opposite of the traditional instructors practices (Barber \& King, 2016). The lack of training of using technologies, computer competencies and perception of students in taking the advantages of online learning are the challenges in online learning for instructors (Martins \& Nunes, 2016). However, an instructor training and experience in the subject seem to be more essential than digital literacy (Kurniawati, et al., 2018). Technology has become the supporting tools in teaching and learning where it is to facilitate instructors in daily academics work (Budnyk et al., (2021). Social characteristics become a vital factor in teaching. Butt, S. (2020) examined the prevailing limited research in quality assessment from the students' perspective; therefore, inputs and service delivery process lead to better service quality and would not obstruct the brand image of the institute. This highlights the importance of students' opinion on a customer value (Rintamaki, et al., 2007).

During the outbreak, students are sent home by the Ministry of Higher Education of Malaysia and they are encouraged to leave their respective dormitory. Most universities in Malaysia, especially Public Universities are equipped with Wi-Fi facilities in almost every space in the university's compound. Thus, it is easier to do online learning on campus. However, at home, especially in the rural and remote area, the students find it hard to find good internet connection, and they need to spend more to purchase internet data (Putri et al., 2020; Purwanto et al., 2020). Online learning during the Covid-19 pandemic is seen to be more costly than the online learning that have been done prior to pandemic (Zahra et al., 2020). The financial and internet restriction becomes the most challenging factors for online learning for students. Moreover, the complicated and non-digital friendly curriculum structure and design have made it even difficult for the students to adapt; thus a re-construction of curriculum is deemed important (Morealle, et al., 2021).

\subsection{Technology Acceptance Model (TAM) in online learning}

TAM has been widely used in determining technology adoption and acceptance in online learning (Ku, 2009; Park, 2009; Farahat, 2012; Al-Azawei \& Lundqvist, 2015; Wingo et al., 2017; Esteban-Millat et al., 2018; Estriegana et al., 2019). It was first introduced by Davis (1989) as a model in predicting the factors of new technology acceptance based on two factors; Perceived Usefulness and Perceived Ease of Use. TAM adjusted from Theory of Reasoned Action (TRA) recommends 
that two important values, seen value and saw convenience, are the important elements for innovation development (Davis, 1989). Perceived usefulness and perceived ease of use are two vital elements in discussing and utilizing the framework (Ajzen $\&$ Fishbien, 1977). Thus, this theory has frequently been used in online learning studies and tested accordingly by variables in TAM to ascertain the effectiveness and usefulness in online learning (Vankatesh, 2000). Previous study also stated that TAM is a good theoretical tool to understand the user's acceptance of online learning or e-learning (Park, 2009; Estriegana, et al., 2019).

TAM has been widely used in determining students' acceptance of online learning (Ku, 2009; Farahat, 2012) and in assisting to shape the students' intention towards online learning (Ku, 2009). However, the existence of external variables are founded in measuring the students' acceptance of online learning such as self-efficacy in using the technology and subjective norms which are important in constructing acceptance of online learning ( $\mathrm{Ku}, 2009$; Park, 2009). Moreover, TAM perceived satisfaction is used as an extension of the existing items in TAM and it is proven that perceived usefulness has a direct impact on the perceived satisfaction of online learning (Al-Azawei et al., 2015). Student's acceptance and adopting online learning environment incorporating clinical and hands-on teaching involving mechanical manipulation, chemical and biological specimens has found that efficiency, playfulness and degree of satisfaction positively influence the original TAM's elements (Estriegana, et al., 2019) although there are a number of difficulties in adopting them. On the other hand, online behavior of students directly influence their conduct in capacity as the users of learning products (Esteban-Millat et al., 2018) meaning that they naturally adopt the online environment acknowledging themselves as students. On the other hand, the faculty perceptions of online learning are more to worry, as they find it as perceived barriers to student success, worrying of their image as online instructor, the needs of technical supports and heavy workload on online learning management (Wingo et al., 2017).

In TAM, perceived usefulness refers to users' acceptance in utilizing the technology and affects their work performance. While perceived ease of use refers to how less hustle of utilizing the technology (Davis, 1989). Both are the determinant components impacting the users' perception of utilizing the technology; however, there are some external factors for the users' perception in utilizing the technology. Thus, such behavior towards utilizing innovation decides the social aim to utilize a particular technology and innovation (Masrom, 2007; Zanuddin, H. \& Shaid, N., 2021). The conceptual framework is designed to see forth alongside with the hypothesis in the framework to determine whether TAM, is useful and effective in online learning. Thus, this model of conceptual framework and research questions are adopted and adapted based on past research to identify the accuracy of the four main variables in the Technology Acceptance Model (TAM) (Masrom, 2007).

However, up to now, categorization of perceived value into both uni- and multi-dimensional concepts are widely used (Boetsch, 2008; Leroi-Werelds \& Streukens, 2011, 2014) and many as reviewed by Zauner et. al (2015). Customers' or students' appraised value depend on sacrifice (monetary and non-monetary costs linked with use of service) customer traits and consumer intention and perceived value. Perceived value (PV) can be assessed with a one-dimensional self-reported scale (Gale, 1994) or a multi-dimensional measure (Petrick \& Backman, 2002; Sheth et al., 1991). Chen and Chen (2010) pointed out that validity of dimensional scale postulated critics on customers mutual meaning of value. Add (Zauner et al., 2015; Sheth et al., 1991) maintained that by operationalizing perceived value (PV), one-dimensional measure could conquer validity issue (Butt, S., 2020).

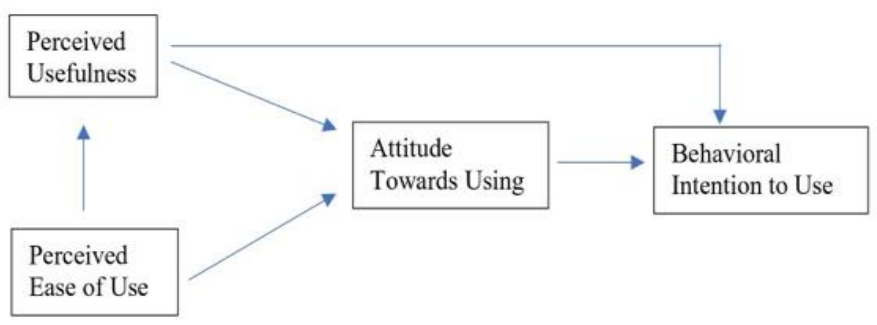

Fig. 1. Technology acceptance model (TAM)

Based on the status quo of the Technology Acceptance Model (TAM) (Masrom, 2007), this present study was guided by the following research questions and hypotheses:

RQ1 - What are the prominent factors determining the attitude of students towards online learning?

H1 - There is a significant relationship between students' perceived usefulness of online learning and attitude towards using

$\mathrm{H} 2$ - There is a strong significant relationship between students' perceived usefulness of online learning towards behavioural intention to use

RQ2 - What is the outcomes of behavioural intention and attitude to use online learning?

H3 - There is a significant relationship between students' perceived use in online learning and attitude towards using

H4 - There is significant relationship between students perceived of use of online learning towards behavioural intention to use

\section{Methodology}

\subsection{Sample}

The sampling method used in this research was the probability sampling method in accordance to the number of samples to be used forth. A likelihood testing characterizes as one in which each unit in the populace gets an opportunity $(0<$ $\mathrm{x}<1$ ) of being chosen in the example, which can be precisely decided. This study was focused on the undergraduate students of University Malaya predominantly in the Department of Media Studies. There were 230 students in the range from firstyear students to final year students in the department. Each of the years of studies consisted of 35 to 60 students. Therefore, the population of the students for this research was assumed to have approximately 230 students.

Approximately 230 students were involved as the population of students; hence, the sample size taken and determined was based on the Krejcie and Morgan's sample size 
(Krejcie \& Morgan, 1970) determination table is 144 samples. This sample size as mentioned followed by Krejcie and Morgan's the computation depends in $p=0.05$ where the likelihood of submitting a sort I mistake is under $5 \%$ or $\mathrm{p}<$ 0.05 .

The table below is the sample size of determination table used in this research according to number of students and sample size taken according to Krejcie and Morgan's sample size.

Table 1. Sample size according to Krejcie \& Morgan (1970)

\begin{tabular}{|c|c|c|c|}
\hline $\mathrm{N} \ldots \mathrm{n}$ & $\mathrm{S} \ldots \mathrm{s}$ & $\mathrm{N} \ldots \mathrm{n}$ & $\mathrm{S} \ldots \mathrm{s}$ \\
\hline 10 & 10 & 100 & 80 \\
\hline 15 & 14 & 110 & 86 \\
\hline 20 & 19 & 120 & 92 \\
\hline 25 & 24 & 130 & 97 \\
\hline 30 & 28 & 140 & 103 \\
\hline 35 & 32 & 150 & 108 \\
\hline 40 & 36 & 160 & 113 \\
\hline 45 & 40 & 170 & 118 \\
\hline 50 & 44 & 180 & 123 \\
\hline 55 & 48 & 190 & 127 \\
\hline 60 & 52 & 200 & 132 \\
\hline 65 & 56 & 210 & 136 \\
\hline 70 & 59 & 220 & 140 \\
\hline 75 & 63 & 230 & 144 \\
\hline 80 & 66 & 240 & 148 \\
\hline 85 & 70 & 250 & 152 \\
\hline 90 & 73 & 260 & 155 \\
\hline 95 & 76 & 270 & 159 \\
\hline
\end{tabular}

\subsection{Instruments}

Quantitative analysis was by focusing on the numerical analysis of data gathered through the distribution of questionnaires and surveys among university students. Also, analyzing the contributing factors to the viability of internet learning among university understudies was to validate the accuracy of this this study.

A set of a questionnaire with 32 questions were divided into four main parts. These set of questions were then customized according to the topic of discussion with a focus on the online learning to measure the perceived usefulness, perceived ease of use, attitude towards using and intention to use in accordance to the original model of TAM. There were two components, i.e. demographic information and TAM component perceived of usefulness, perceived of use, attitude towards using and intention to use to evaluate the effectiveness of online learning among students. Pilot study was administered to gauge to the instrument reliability and validity.

The respondents were undergraduate students from first year to final year of Department Media and Communication Studies, University of Malaya who were using online learning throughout their courses. Since the MCO was introduced to Malaysia to contain Covid-19 from spreading, respondents were asked with a set of questions indicating with their arrangement or conflict with each statement on a 5-point Likert-type scale. Here, the respondents made the endpoint choices being unequivocally dissent and emphatically concur in their opinion on online learning perceived usefulness.

\subsection{Validity and reliability}

Estimation legitimacy as far as dependability and development legitimacy was assessed. The unwavering quality examination was led to ensure the authenticity and consistency of the things used for each factor. Hair et al., (1998) recommended that Cronbach's Alpha characteristics from 0.6 to 0.7 are regarded as the farthest reaches of pleasantness. However, with more than 0.7 would show that the things are homogeneous and assessing a comparable steady. Table 1 depicted the unwavering quality of the estimation measures. This Cronbach's Alpha unwavering quality measures were pervasive 0.8, viewed as awesome (Nunnally, 1978). Consequently, the outcomes exhibited that the poll was a dependable estimation instrument. Based on the pilot test of respondents, the Cronbach Alpha result showed a significant strong instrument reliability and validity. There is no suggestion to amend or drop any statement from the survey as stated in table 2 .

Table 2. Reliability reading cronbach's alpha

\begin{tabular}{lc}
\hline \multicolumn{1}{c}{ Scale } & Cronbach's Alpha \\
\hline Perceived Ease of Use & 0.89 \\
Perceived Usefulness & 0.89 \\
Attitude Towards Using & 0.85 \\
Intention to Use & 0.85 \\
\hline
\end{tabular}

\section{Data analysis}

This research adopted a quantitative research approach. Data were analyzed using the statistical package of social science (SPSS) and statistical of factor analysis. Exploratory Factor Analysis (EFA) was performed to examine whether the two factors, in TAM Model; Perceived Usefulness and Perceived Ease of Use were able to verify a relationship between students' attitude towards using and behavioral intention to use. SPSS was employed to extract the factors using EFA with varimax rotation employed for factor extraction and rotation respectively. These methods are appropriate for extraction and rotation in the exploratory factor analysis (Costello \& Osborne, 2005; Mohamed, A. et al., 2020).

\section{Results}

In this research, a survey form was distributed to the undergraduate students based on Krejcie \& Morgan sample size formula. A total of 144 respondents successfully returned the online survey via Google Form. Table 3 showed the distribution of the respondents based on the particular year of study in Department of Media \& Communication Studies, Faculty of Arts \& Social Sciences, University of Malaya. Table 4 shows that $84 \%$ of the age group of respondents were between 20 and 22. The higher number of female respondents prevailed a $73.6 \%$ compared to $26.4 \%$ of male respondents consecutively. 
Table 3. Distribution of respondents data

\begin{tabular}{lcc}
\hline \multicolumn{1}{c}{ Age } & Frequency & Percent $(\%)$ \\
\hline $20-22$ & 121 & 84.0 \\
$23-25$ & 1 & 0.7 \\
$26-30$ & 22 & 15.3 \\
Total & 144 & 100.0 \\
\multicolumn{1}{c}{ Sex } & Frequency & Percent $(\%)$ \\
Female & 106 & 73.6 \\
Male & 38 & 26.4 \\
Total & 144 & 100.0 \\
Year Of Study & Frequency & Percent $(\%)$ \\
First Year & 40 & 27.8 \\
Second Year & 63 & 43.8 \\
Third Year & 35 & 24.3 \\
Fourth Year & 6 & 4.2 \\
Total & 144 & 100.0 \\
\hline
\end{tabular}

\subsection{Students' Perceived Usefulness of Online Learning}

The KMO coefficient of sampling adequacy reported 863 greater than 0.50 . The Barlett's Test of sphericity was significant $\mathrm{x} 2(\mathrm{~N}=8)=538.005, \mathrm{p}<.05($ table 4$)$. Both results indicated that this factor was applicable for factor analysis.

Table 4. KMO and Barlett's test

\begin{tabular}{|c|c|c|}
\hline \multicolumn{3}{|c|}{ KMO and Bartlett's Test } \\
\hline Kaiser-Meyer-Oll & Sampling Adequacy. & 0.863 \\
\hline Bartlett's Test of & Approx. Chi-Square & 538.005 \\
\hline \multirow[t]{2}{*}{ Sphericity } & $\mathrm{df}$ & 28 \\
\hline & Sig. & 0.000 \\
\hline
\end{tabular}

Table 5. Communalities

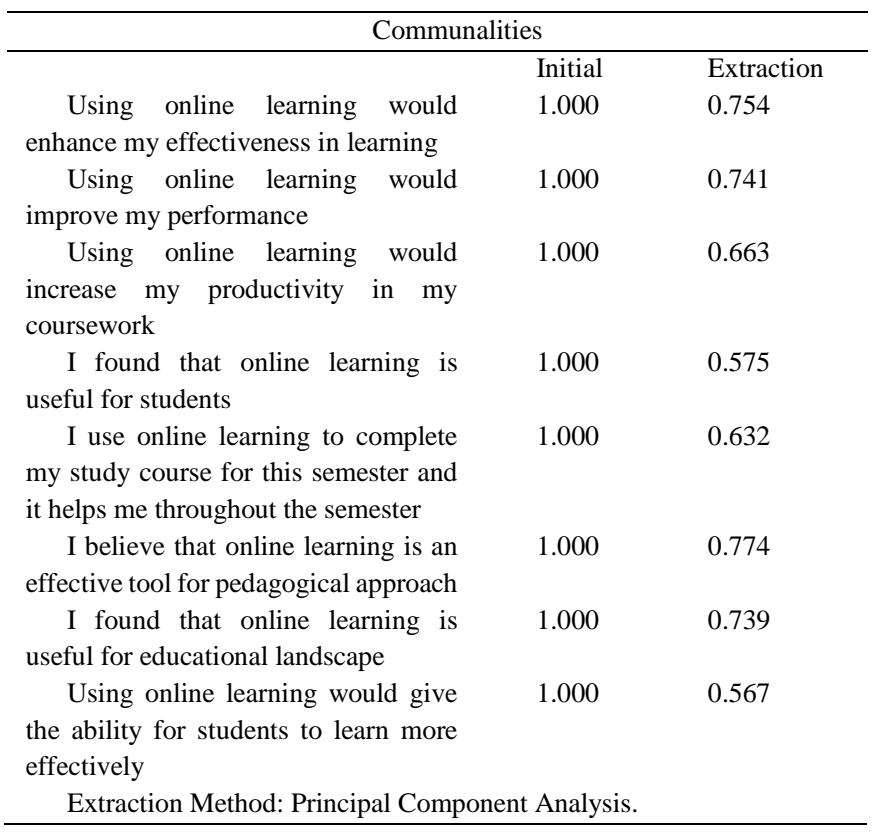

The communality measured the percent variance in a given variable as explained by all items jointly ( $n=8$ items). No item was extracted as the communalities statistics among the item were found more than 0.50 .

After the factor extraction, Kaiser's criterion was applied to retain items with Eigenvalues larger than 1.0. Two components were extracted.

Table 6. Eigenvalues

\begin{tabular}{cccc}
\hline Component & Total & $\begin{array}{c}\text { Initial Eigenvalues } \\
\text { \% of Variance }\end{array}$ & Cumulative \% \\
\hline 1 & $4.306^{*}$ & 53.820 & 53.820 \\
2 & $1.140^{*}$ & 14.255 & 68.075 \\
3 & 0.619 & 7.742 & 75.817 \\
4 & 0.539 & 6.736 & 82.553 \\
5 & 0.433 & 5.416 & 87.969 \\
6 & 0.414 & 5.177 & 93.146 \\
7 & 0.331 & 4.143 & 97.290 \\
8 & 0.217 & 2.710 & 100.000 \\
\hline
\end{tabular}

However, literature depicted that by solely depending on the eigenvalues can be slightly inaccurate. Therefore, to be more accurate, another way of determining factor is through the use of scree plot that results in one dimension. Hence, the researcher justified the number of factors through forcing the number of factors to be extracted as one as per the result as shown in the scree plot.

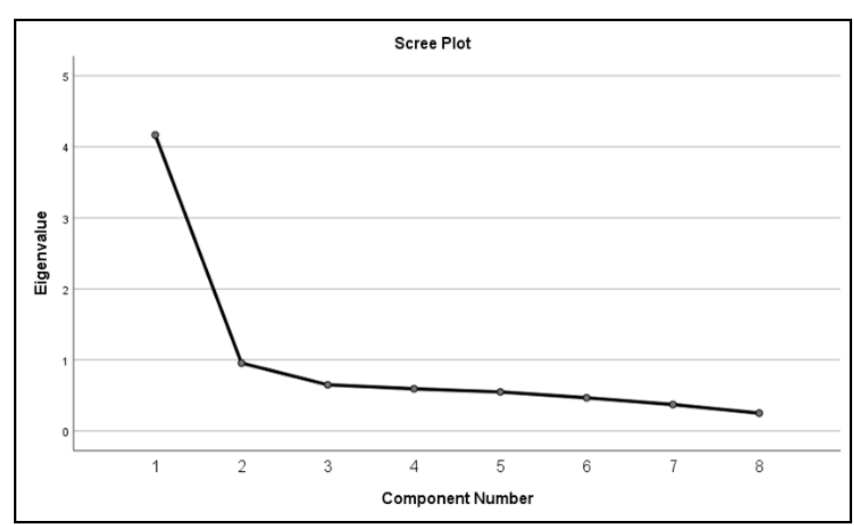

Fig. 2. Scree plot

After identifying the component based on an examination of eigenvalues and scree plot, rotation was done by varimax method. The items with 0.5 loadings or greater were considered practically significant. Table 7 shows that 'Using Online Learning Will Enhance My Effectiveness in Learning' 0.864 and 'Using Online Learning Would Improve my Performance' 0.849 were extracted based on their factor loadings

Table 7. Factors loading

\begin{tabular}{lllll}
\hline \multicolumn{1}{c}{ Items } & $\begin{array}{c}\text { Eigenvalu } \\
\text { es }\end{array}$ & $\begin{array}{c}\text { Variance } \\
(\%)\end{array}$ & $\begin{array}{c}\text { Cumulative } \\
\text { of Total } \\
\text { Variance }(\%)\end{array}$ & Loading \\
\hline $\begin{array}{l}\text { Online } \\
\text { learning } \\
\text { enhanced } \\
\text { effectiveness }\end{array}$ & 4.306 & 53.820 & 53.820 & 0.864 \\
$\begin{array}{l}\text { in learning } \\
\begin{array}{l}\text { Improve study } \\
\text { performance }\end{array}\end{array}$ & 1.140 & 14.255 & 68.072 & 0.849 \\
\hline
\end{tabular}




\subsection{Students Attitude towards Online Learning}

The KMO coefficient of sampling adequacy reported .868 greater than 0.50 . The Barlett's Test of sphericity was significant $\mathrm{x} 2(\mathrm{~N}=8)=497.835, \mathrm{p}<.05$ (table 8$)$. Both results indicated that this factor was applicable for factor analysis.

Table 8. KMO and Barlett's test

\begin{tabular}{llc}
\hline \multicolumn{2}{c}{ KMO and Bartlett's Test } \\
\hline Kaiser-Meyer-Olkin Measure of Sampling Adequacy. & 0.868 \\
Bartlett's Test of Sphericity & Approx. Chi-Square & 497.835 \\
& Df & 28 \\
& Sig. & 0.000 \\
\hline
\end{tabular}

The communality measured the percent variance in a given variable as explained by all items jointly ( $\mathrm{n}=8$ items). One item was extracted as the communalities statistics among the item was found less than 0.50 , which is first item I believe online learning can solve my problems in my coursework (.483).

Table 9. Communalities measures

\begin{tabular}{|c|c|c|}
\hline \multicolumn{3}{|c|}{ Communalities } \\
\hline & Initial & Extraction \\
\hline $\begin{array}{l}\text { I believe that online learning can } \\
\text { solve my problems in my } \\
\text { coursework }\end{array}$ & 1.000 & 0.483 \\
\hline $\begin{array}{l}\text { I believe that using online learning } \\
\text { is a bad idea throughout my } \\
\text { coursework }\end{array}$ & 1.000 & 0.645 \\
\hline $\begin{array}{l}\text { I am positive towards online } \\
\text { learning and its usefulness to help } \\
\text { my studies }\end{array}$ & 1.000 & 0.715 \\
\hline $\begin{array}{l}\text { I believe that online learning will } \\
\text { help me ace in my study } \\
\text { performance and my assignments }\end{array}$ & 1.000 & 0.774 \\
\hline $\begin{array}{l}\text { I perceive that online learning is a } \\
\text { better tool to for all students to } \\
\text { replace physical classes }\end{array}$ & 1.000 & 0.689 \\
\hline $\begin{array}{l}\text { I believe that online learning will } \\
\text { give input for my course } \\
\text { throughout my semester }\end{array}$ & 1.000 & 0.710 \\
\hline $\begin{array}{l}\text { I believe that online learning gives } \\
\text { exposure to all students in } \\
\text { strengthen their performance in } \\
\text { study }\end{array}$ & 1.000 & 0.696 \\
\hline $\begin{array}{l}\text { I am positive towards online } \\
\text { learning and its advantages to all } \\
\text { students }\end{array}$ & 1.000 & 0.619 \\
\hline Extraction Method: Principal Co & nent Anc & \\
\hline
\end{tabular}

EFA was conducted again with the exclusion of the item as mentioned above with low communalities. The communalities statistics among the items $(\mathrm{N}=7)$ were found to be departed the-cut-off-point of 0.50 for inclusion in the component matrix.

After the factor extraction, Kaiser's criterion was applied to retain items with eigenvalues larger than 1.0. There was one component being extracted.

However, literature depicted that solely depending on the eigenvalues can be slightly inaccurate. Therefore, to be more accurate, another way of determining factor is through the use of scree plot. The scree plot resulted in one dimension. Hence, the researcher justified the number of factors through forcing the number of factors to be extracted as one as per the result as showed in the scree plot.

Table 10. Communalities

\begin{tabular}{|c|c|c|}
\hline \multicolumn{3}{|c|}{ Communalities } \\
\hline & Initial & Extraction \\
\hline $\begin{array}{l}\text { I believe that using online } \\
\text { learning is a bad idea throughout } \\
\text { my coursework }\end{array}$ & 1.000 & 0.626 \\
\hline $\begin{array}{l}\text { I am positive towards online } \\
\text { learning and its usefulness to help } \\
\text { my studies }\end{array}$ & 1.000 & 0.746 \\
\hline $\begin{array}{l}\text { I believe that online learning } \\
\text { will help me ace in my study } \\
\text { performance and my assignments }\end{array}$ & 1.000 & 0.766 \\
\hline $\begin{array}{l}\text { I perceive that online learning } \\
\text { is a better tool to for all students to } \\
\text { replace physical classes }\end{array}$ & 1.000 & 0.709 \\
\hline $\begin{array}{l}\text { I believe that online learning } \\
\text { will give input for my course } \\
\text { throughout my semester }\end{array}$ & 1.000 & 0.736 \\
\hline $\begin{array}{l}\text { I believe that online learning } \\
\text { gives exposure to all students in } \\
\text { strengthen their performance in } \\
\text { study }\end{array}$ & 1.000 & 0.707 \\
\hline $\begin{array}{l}\text { I am positive towards online } \\
\text { learning and its advantages to all } \\
\text { students }\end{array}$ & 1.000 & 0.627 \\
\hline
\end{tabular}

Table 11. Eigenvalues

\begin{tabular}{llll}
\hline Component & \multicolumn{3}{c}{ Initial Eigenvalues } \\
& Total & \% of Variance & Cumulative \% \\
\hline 1 & $3.832^{*}$ & 54.741 & 54.741 \\
2 & $1.083^{*}$ & 15.472 & 70.213 \\
3 & 0.496 & 7.084 & 77.297 \\
4 & 0.484 & 6.920 & 84.218 \\
5 & 0.452 & 6.463 & 90.680 \\
6 & 0.358 & 5.114 & 95.794 \\
7 & 0.294 & 4.206 & 100.000 \\
\hline
\end{tabular}

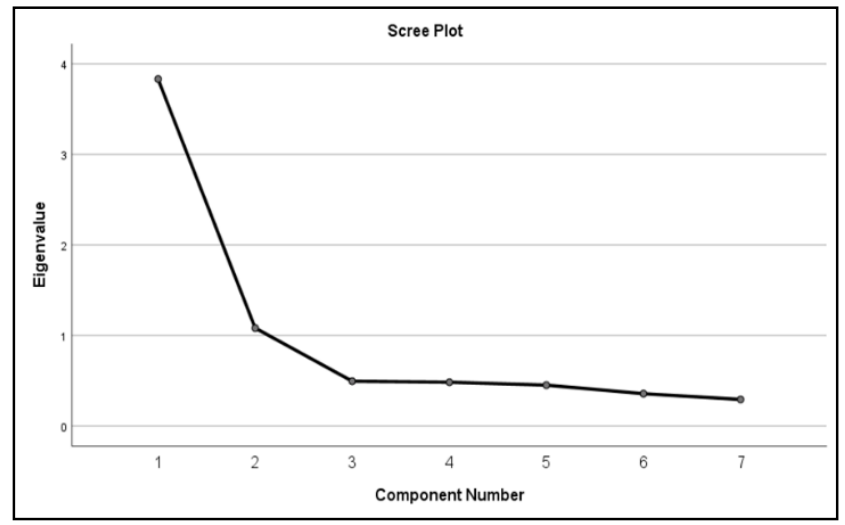

Fig. 3. Scree plot

After identifying the component based on an examination of eigenvalues and scree plot, rotation was done by varimax method. The items with 0.5 loadings or greater were considered 
practically significant. Table 12 shows that 'Online learning is a bad idea' 0.762 and 'I am positive towards online learning and its useful to help in my studies' 0.816 were extracted based on their factor loadings.

Table 12. Factors loading

\begin{tabular}{lcccr}
\hline \multicolumn{1}{c}{ Items } & Eigenvalues & $\begin{array}{c}\text { Variance } \\
(\%)\end{array}$ & $\begin{array}{c}\text { Cumulative } \\
\text { of Total } \\
\text { Variance }(\%)\end{array}$ & Loading \\
\hline $\begin{array}{l}\text { Online } \\
\text { learning is a } \\
\text { bad idea }\end{array}$ & 3.832 & 54.741 & 54.741 & 0.762 \\
$\begin{array}{l}\text { Positive } \\
\text { towards } \\
\text { online } \\
\text { learning as it } \\
\text { helps } \\
\text { studies in }\end{array}$ & 1.083 & 15.472 & 70.213 & 0.816 \\
\hline
\end{tabular}

\section{Discussion}

\subsection{Perceived of usefulness of online learning}

Based on the factors that retained with 0.5 loadings and eigenvalues more than 1 , the most contributing factors of perceived of usefulness of online learning were online learning enhanced effectiveness in learning and it improved their performance in study. With the outbreak of Covid-19 pandemic, the students has no choice but to embrace and enhance the online learning although there are too many challenges of virtual learning at home. However, it cannot be denied that technology has made distance education easier (McBrien et al., 2009). Synchronous learning or virtual live learning brings much more opportunities of social interaction in comparison to recording lectures (McBrien et al., 2009). Online learning has made it possible to have all the elements of a physical classes in online platforms such as; (1) possibility to gather 40-50 students at once in a video conferencing, (2) possibility to real-time two-way communication and discussion, (3) accessible through gadgets such as mobile phones, tablets, computers and laptops, and (4) instant feedback from students and assignments can be distributed (Basilaia, et al., 2020).

This health crisis has forced the institution to accept online mode pedagogy and provide ample tools and provide options for instructors to communicate with students (Dhawan, 2020). To adapt with the changing situation, the institution is responsible for providing the quality education and perform online learning in such huge manner (Carey, 2020). Thus, based on the results, University of Malaya (UM) have done quite a good job in ascertaining that their stakeholders are in well-equipped in delivering and accepting knowledge in online platforms. Institutional license has been acquired by UM in order for instructors and students easy usage of online video conferencing and platform such as Microsoft Teams and Google Meet allowing them to have a smooth and stable interaction online. This is a big help that contributes to the undergraduate students in perceived of usefulness of online learning.

\subsection{Students' attitude towards online learning}

Based on the Exploratory Factor Analysis, factors retained with more than 1 Eigenvalues and 0.5 loadings describing students' attitude towards online learning were both negative and positive; online learning is a bad idea 0.762 and they are positive towards online learning as it is helps in their studies 0.816 . This result showed that the students partially felt that the online learning is effective in their studies. For the online is a bad idea, most students relate the feeling of unhappiness for not being able to participate Face-to-Face (F2F) lab classes such as video editing, graphic designing and broadcasting technical facilities in campus. The bad idea in the findings relates deeper to the challenges faced by the students during the outbreak where they have been forced to leave their dormitories and go back to their hometown where internet connection is not always stable compared to free $\mathrm{Wi}-\mathrm{Fi}$ as provided by University of Malaya. The burden of financial circumstances is faced by not only them but also their parents, as they are unable to buy sufficient internet data (Putri et al., 2020; Purwanto et al., 2020). Thus, they find it very inconvenient for them to get into classes online where they cannot listen to F2F lecture and collaborate in real-time discussion as the internet connection is not always stable. Furthermore, natural disaster such as flood occurred during the semester that hit six states in Malaysia such as in Kelantan, Trengganu, Pahang, Johor, Perak and Selangor made the online learning impossible due to no electricity and internet data cut-off (Berita Harian, January 2021, The Star, 2020). Special assistance were relayed to the students involved such as extended deadline for alternative examinations and coursework. Nonetheless, as suggested by Morreale et al. (2021), communication researchers need to answer the critical question on how students can learn most efficaciously in an online environment since based on the result of this study they are on the rock to agree on online learning. The digital medium does not work the same as the physical classes. Thus, new curriculum shall be designed to increase the effectiveness of online learning. Another study also suggested to reconstruct the module offered to students and the way of communicating through online as trauma inflicted by the pandemic with sudden lockdown orders by the government has affected the students. Instructors activates a mind-set that energizers innovative approaches through communication instructions (Schwartzman, R., 2020).

Zahra et al. (2020) mentioned that online learning is much more costly, and government, Ministry of Higher Education Malaysia (MOHE) play a role in providing the incentive of targeted Internet Data Plan and Device Assistance to B40 category students (under privilege students) on $30^{\text {th }}$ October 2020. According to MOHE media release, an amount of 195,028 internet data plan and 3,773 devices were distributed until $31^{\text {st }}$ December 2020 and the Ministry obtained other 3,997 devices for distribution. Moreover, the government committed in dealing with telecommunication companies in Malaysia in providing the best and cheaper internet data plan deals for higher education students.

\section{Conclusion}

The result found that online learning is useful among the 
media and communication students because it can enhance effectiveness in learning and it helps to improve the performance in their study. However, it was found that from the attitude of students towards online learning they are partially unhappy with it. Even though learning process is affective, but as mentioned above, the lack of 'human touch' made it an unpleasant experience. The model of community learning (Garrison et al., 1999) explained that deep and meaningful learning environment resulted with the sufficient level of three components; (1) cognitive presence, (2) social presence and (3) teaching presence. Thus, the adoption of the presence of these elements is needed to complete a meaningful and effective online learning environment. Furthermore, with the restriction to conduct physical studio-based classes, it makes it difficult for media and communication students to fulfill technical broadcasting subjects. Further research can be done to fill the gap with different sample of students with different major in university or primary or secondary school students.

\section{References}

Adnan, M., \& Anwar, K. (2020). Online learning amid the Covid-19 pandemic: Students' perspective. Journal of Pedagogical Sociology and Psychology, 2(1), 45-51.

Al-Azawei, A., \& Lundqvist, K. (2015). Learner differences in perceived satisfaction of an online learning: An extension to the technology acceptance model in an Arabic sample. Electronic Journal of ELearning, 13(5), 412-430.

Basilaila, G., Dgebuadze, M., Kantaria, M., \& Chokhonelidze, G. (2020). Replacing the classic learning from at universities as an immediate response to Covid-19 virus infection in Georgia. International Journal for Research in Applied Science \& Engineering Technology, 8(3), 101-108.

Basilaia, G. \& Kvavadze, D. (2020). Transition to online education in schools during a SARS-CoV-2 Coronavirus Covid-19 in Georgia Pedagogical Research, 5(4), 1-9.

Berita Harian. (2021). Banjir di enam negeri, lebih 16,500 mangsa dipindahkan (Flood in six states, more than 16,500 victims evacuated). January $4 . \quad$ Retrived from https://www.bharian.com.my/berita/nasional/2021/01/771865/banjir -di-enam-negeri-lebih-16500-mangsa-dipindahkan

Boestch, T.C. (2008). An approach to customer value-based product design: An analysis using the example of product design in the airline industry. PhD Thesis. University St. Gallen, St. Gallen, Switzerland.

Budnyk, O., Zozuliak-Sluchyk, R., Nedilskyi, S., Chervinska, I., Malaniuk, T., Prevysokova, N., \& Ketsyk-Zinchenko, U. (2021). Modern digital distance learning technologies: challenges of future teacher training. Revista Inclusiones, 8(1), 41-53.

Butt, S. (2020). Service quality assessment and student satisfaction in business schools: Mediating role of perceived value. Malaysian Online Journal of Educational Management, 9(1), 58-76

Carey, K. (2020). Is everybody ready for the big migration to online college? Actually, no. The New York Times. http://theirworld.org.

Chen, F. S. (2010) Experiencing quality, perceived value, satisfaction and behavioral intentions for heritage tourists. Tourism Management, 31(1), 29-35

Demuyakor, J. (2020). Coronavirus (COVID-19) and Online Learning in Higher Institutions of Education: A Survey of the Perceptions of
Ghanaian International Students in China. Online Journal of Communication and Media Technologies, 10(3), e202018.

Dhawan, S. (2020). Online learning: A Panacea the Time of Covid-19 Crisis. Journal of Educational Systems, 49(1), 5-22.

Esteban-Millat, I., Martínez-López, F. J., Pujol-Jover, M., Gázquez-Abad, J. C., \& Alegret, A. (2018). An extension of the technology acceptance model for online learning environments. Interactive Learning Environments, 26(7), 895-910.

Estriegana, R., Medina-Merodio, J. A., \& Barchino, R. (2019). Student acceptance of virtual laboratory and practical work: An extension of the technology acceptance model. Computers \& Education, 135, 114.

Farahat, T. (2012). Applying the technology acceptance model to online learning in the Egyptian universities. Procedia - Social and Behavioral Sciences, 64, 95-104.

Garrison, D. R., Anderson, T., \& Archer, W. (1999). Critical inquiry in a textbased environment: Computer conferencing in higher education. The internet and higher education, 2(2-3), 87-105.

Krejcie, R. V., \& Morgan, D. W. (1970). Determining sample size for research activities. Educational and psychological measurement, 30(3), 607610.

$\mathrm{Ku}, \mathrm{C} . \mathrm{H}$. (2009). Extending the technology acceptance model using perceived user resources in higher education web-based online learning courses. University of Central Florida.

Kurniawati, N., Maolida, E. H., \& Anjaniputra, A. G. (2018). The praxis of digital literacy in the Efl classroom: digital-immigrant vs digitalnative teacher. Indonesian Journal of Applied Linguistics, 8(1), 2837.

Leroi-Werelds, S., \& Streukens, S. (2011). Customer value measurement. Marketing Science Institute Working Paper Series.

Leroi-Werelds, S., Streukens, S., Brady, M. K., \& Swinnen, G. (2014). Assessing the value of commonly used methods for measuring customer value: a multi-setting empirical study. Journal of the academy of marketing science, 42(4), 430-451.

McBrien, J.L., Cheng, R., \& Jones, P. (2009). Virtual spaces: Employing a synchronous online classroom to facilitate student engagement in online learning. The International Review of Research in Open and Distributed Learning, 10(3), 1-17.

Mohamed, A., Abdullah, Z., \& Razak, A. Z. A. (2020). Validation Of An Instrument For Measuring Integrated Principal Leadership Practices. MOJEM: Malaysian Online Journal of Educational Management, 9(1), 1-20.

Morreale, S. P., Thorpe, J., \& Westwick, J. N. (2021). Online teaching: challenge or opportunity for communication education scholars?. Communication Education, 70(1), 117-119.

Park, S. Y. (2009). An analysis of the technology acceptance model in understanding university students' behavioral intention to use elearning. Journal of Educational Technology \& Society, 12(3), 150162.

Petrick, J. F., \& Backman, S. J. (2002). An examination of the construct of perceived value for the prediction of golf travelers' intentions to revisit. Journal of travel research, 41(1), 38-45.

Rintamäki, T., Kuusela, H., \& Mitronen, L. (2007). Identifying competitive customer value propositions in retailing. Managing Service Quality: An International Journal, 17(6), 621-634.

Schwartzman, R. (2020). Performing pandemic pedagogy. Communication Education, 69(4), 502-517.

Sheth, J. N., Newman, B. I., \& Gross, B. L. (1991). Why we buy what we buy: A theory of consumption values. Journal of business research, 22(2), 159-170. 
The Star. (2020). Floods: situation worsen in east coast. December 18. Retrived from https://www.thestar.com.my/news/nation/2020/12/18/floodssituation-worsens-in-east-coast

Wingo, N. P., Ivankova, N. V., \& Moss, J. A. (2017). Faculty perceptions about teaching online: Exploring the literature using the technology acceptance model as an organizing framework. Online Learning, 21(1), 15-35.
Zanuddin, H., \& Shaid, N. (2021). Social perceived value on social media and online news portal: benefits to the aborigines women in Malaysia. International Journal of Interactive Mobile Technologies (iJIM), 15(04), 61-72.

Zauner, A., Koller, M., \& Hatak, I. (2015). Customer perceived valueConceptualization and avenues for future research. Cogent Psychology, 2(1), 1061782. 